J. Clin. Chem. Clin. Biochem.

Vol. 17, 1979, pp. 309-313

\title{
Determination of Oxalate in Urine Using Oxalate Oxidase: Comparison with Oxalate Decarboxylase
}

\author{
By G. Kohlbecker, Liselotte Richter and M. Butz \\ Institut für Molekularbiologie und Biochemie, Freie Universität Berlin, \\ und Urologische Klinik und Poliklinik, Klinikum Steglitz, Freie Universität Berlin
}

(Received October 27, 1978/January 11, 1979)

Dedicated to Prof. Dr. Dr. Ernst Schütte on the occasion of his 70 th birthday

Summary: The oxalate content of urine is determined by means of oxalate oxidase and simple $\mathrm{pH}$ measurement. The enzyme specifically decarboxylates oxalate, producing two moles $\mathrm{CO}_{2}$ per mole oxalate. The $\mathrm{CO}_{2}$ diffuses into an alkaline buffer solution (Hallson, P. C. \& Rose, G. A. (1974), Clin. Chim. Acta 55, 29-39) in the closed reaction vessel, and reduces the $\mathrm{pH}$ value, which is measured with an electrode. Only $125 \mu \mathrm{l}$ native urine is required to measure oxalate concentrations in the range of $80 \mu \mathrm{mol} / 1$ to $1.6 \mathrm{mmol} / \mathrm{l}$ (corresponding to 7 to $144 \mathrm{mg}$ anhydrous oxalic acid per liter). The limit of detection is $10 \mathrm{nmol}$ oxalate, and the accuracy is $101 \%$ with a coefficient of variation of $6 \%$.

The method described is insensitive to various interfering factors, such as reducing and oxidizing substances, cloudy or colored samples. It is therefore also suitable for oxalate determination in food technology and plant breeding.

\section{Bestimmung von Oxalat in Urin mit Oxalat-Oxidase: Vergleich mit Oxalat-Decarboxylase}

Zusammenfassung: Der Oxalatgehalt von Urin wird mittels Oxalat-Oxidase durch einfache pH-Messung bestimmt. Das Enzym decarboxyliert spezifisch Oxalat, wobei je Mol Oxalat zwei $\mathrm{Mol} \mathrm{CO}_{2}$ entstehen. Durch Diffusion des $\mathrm{CO}_{2}$ in eine alkalische Pufferlösung (Hallson, P. C. \& Rose, G. A. (1974), Clin. Chim. Acta 55, 29-39) in geschlossenen Reaktionsgefaßßen erniedrigt sich der pH-Wert, der mit einer Elektrode gemessen wird. Dabei genügen $125 \mu \mathrm{l}$ Nativ-Urin, um Oxalatkonzentrationen im Meßbereich von $80 \mu \mathrm{mol} / 1$ bis $1,6 \mathrm{mmol} / 1$ (entsprechend $7 \mathrm{mg}$ bis $144 \mathrm{mg}$ wasserfreie Oxalsäure je 1) żu erfassen. Die Nachweisgrenze liegt bei 10 nmol Oxalat, die Richtigkeit beträgt $101 \%$ bei einem Variationskoeffizienten von $6 \%$.

Die beschriebene Methode zeichnet sich durch geringe Störanfälligkeit gegenüber verschiedenartigen Analysenproben aus. Reduzierende und oxidierende Substanzen, trübes und gefärbtes Untersuchungsmaterial stören nicht. Sie ist deshalb auch für Oxalatbestimmungen in der Lebensmitteltechnologie und Pflanzenzüchtung geeignet.

\section{Introduction}

The determination of oxalate in urine has become clinically important for the recognition and treatment of various forms of hyperoxaluria. In addition, the oxalate excretion of patients with calcium oxalatelithiasis has come into the center of attention in clinical urinary stone research. Outside of medicine, an exact and simple method for oxalate determination is needed in food technology and plant breeding.

Many methods have been described in the literature; Hodgkinson (2) provides a review. All previously described enzymatic techniques are based on the enzyme oxalate decarboxylase (oxalate carboxy-lyase,

EC 4.1.1.2), which converts oxalate to $\mathrm{CO}_{2}$ and formate:

$$
(\mathrm{COOH})_{2} \stackrel{\text { decarboxylase }}{\longrightarrow} \mathrm{CO}_{2}+\mathrm{HCOOH}
$$

Each of the reaction products can be quantitatively measured by well-known methods (3).

If $\mathrm{CO}_{2}$ is to be measured, the use of oxalate oxidase (oxalate: oxygen oxidoreductase, EC 1.2.3.4), which has not previously been used for oxalate determination 
seems advantageous, because it produces two moles $\mathrm{CO}_{2}$ from one mole oxalate (4):

$$
(\mathrm{COOH})_{2}+\mathrm{O}_{2} \stackrel{\text { oxidase }}{\longrightarrow} 2 \mathrm{CO}_{2}+\mathrm{H}_{2} \mathrm{O}_{2}
$$

Furthermore, the enzyme catalase (hydrogen-peroxide: hydrogen-peroxide oxidoreductase, EC 1.11.1.6) can be used to decompose the $\mathrm{H}_{2} \mathrm{O}_{2}$ produced:

$$
\mathrm{H}_{2} \mathrm{O}_{2} \stackrel{\text { catalase }}{\longrightarrow} 1 / 2 \mathrm{O}_{2}+\mathrm{H}_{2} \mathrm{O}
$$

The coupled reaction thus achieves a rapid, quantitative conversion of oxalate, and requires only half as much oxygen as the oxidase reaction by itself:

$$
(\mathrm{COOH})_{2}+1 / 2 \mathrm{O}_{2} \stackrel{\text { oxidase, catalase }}{\longrightarrow} 2 \mathrm{CO}_{2}+\mathrm{H}_{2} \mathrm{O}
$$

We used this reaction as a basis for the development of a method for oxalate determination in urine. The reaction takes place in a closed vessel in a buffer with a $\mathrm{pH}$ value of 3.8. The $\mathrm{CO}_{2}$ is released from the acidic buffer and diffuses into an alkaline buffer solution and causes its $\mathrm{pH}$ value to decrease (1), in linear proportion to the amount of oxalate present.

\section{Materials and Methods}

\section{Reagents}

All chemicals were obtained in p. a. grade from Merck AG (Darmstadt). Bovine liver catalase, about $65000 \mathrm{U} / \mathrm{mg}$, corresponding to $1.3 \mathrm{GU} / 1$ (Boehringer Mannheim $\mathrm{GmbH}$ ), was diluted before use 1: 5 with succinate buffer (see below). We used oxalate decarboxylase from Worthington, and we purified oxalate oxidase from barley seedlings (5). The purification steps were extraction with $\mathrm{H}_{2} \mathrm{O}$, heat denaturation of $\mu \mathrm{n}$ desired proteins, fractional ammonium sulfate precipitation (45-65\%) and ion-exchange chromatography on DEAE-Sephadex A-50, with imidazole buffer, $\mathrm{I}=0.05, \mathrm{pH}$ 8. The enzyme was eluted with a $\mathrm{NaCl}$ gradient. From $1 \mathrm{~kg}$ seedlings we obtained $6 \mathrm{mg}$ protease- and catalase-free enzyme protein with a specific activity of about $15 \mathrm{U} / \mathrm{mg}\left(37^{\circ} \mathrm{C}\right.$, succinate buffer, $\mathrm{pH}$ 3.8). Partially purified enzyme preparations containing catalase activity also suffice for oxalate determination, but for reasons of stability, they should not contain protease. The preparation was stable as a solution in succinate buffer $(2 \mathrm{~g} / \mathrm{l})$ containing merthiolate $(20 \mathrm{mg} / \mathrm{l})$ for at least 3 months at $4^{\circ} \mathrm{C}$. Before use it was diluted with succinate buffer (see below) 1: 40 . Therefore the applied $400 \mu \mathrm{l}$ contained $20 \mu \mathrm{g}$ enzyme protein (about $0.3 \mathrm{U}$ ). Since many factors affect the determination of enzyme activity, the amounts of enzyme used are given here as $\mu \mathrm{g}$ protein of our preparation.

\section{Solutions}

All solutions were prepared with doubly distilled water from which $\mathrm{CO}_{2}$ had been removed by vacuum distillation. $\mathrm{O}_{2}$ was bubbled through for $30 \mathrm{~min}(1 \mathrm{l} / \mathrm{min})$ before use.

I. $50 \mathrm{mmol} / 1$ succinate buffer, $\mathrm{pH} 3.8+5 \mathrm{mmol} / \mathrm{l}$ EDTA: Dissolve $5.9 \mathrm{~g}$ succinic acid $+1.86 \mathrm{~g}$ EDTA in about $900 \mathrm{ml}$ $\mathrm{H}_{2} \mathrm{O}$, adjust to $\mathrm{pH} 3.8$ with $1 \mathrm{~mol} / \mathrm{l} \mathrm{NaOH}$ and fill to 11 with $\mathrm{H}_{2} \mathrm{O}$.

II. Alkaline buffer $\mathrm{pH} 10$

Stock solution: $4.8 \mathrm{~g} \mathrm{Na}_{2} \mathrm{CO}_{3}+6.7 \mathrm{~g} \mathrm{NaHCO}$ dissolved in $100 \mathrm{ml} \mathrm{H} \mathrm{H}_{2} \mathrm{O}$. Before use, dilute 1; 800 with $\mathrm{H}_{2} \mathrm{O}$.

III. Oxalate standard solution $(100 \mu \mathrm{mol} / \mathrm{l})$ : Dissolve $12.6 \mathrm{mg}$ oxalic acid $2 \mathrm{H}_{2} \mathrm{O}\left(M_{\mathrm{r}} 126.07\right)$ in about
$900 \mathrm{ml}$ succinate buffer. Adjust to $\mathrm{pH} 3.8$ with $1 \mathrm{~mol} / 1$ $\mathrm{NaOH}$, then fill to 11 with buffer.

\section{Equipment}

$\mathrm{pH}$ meter, readable to $0.01 \mathrm{pH}$.

Micro combined $\mathrm{pH}$ electrode

Optional: shaking apparatus for the reaction vessels. We used the thermostatic shaking bath from B. Braun (Melsungen), but without the thermostat.

Oxygen pressure bottle with a reducing valve.

Conical Warburg reaction flask from B. Braun (Melsungen), No. 830415 , with a total volume of about $13 \mathrm{ml}$. The central inner well holds a shortened Eppendorf-Netheler cup (Eppendorf Gerätebau, Hamburg, No. 3810) for the alkaline buffer solution. This plastic cup has a small piece of tubing pulled over its conical end, so that it sits more firmly in the central well, The main glass joint is closed with a stopcock, bore $1.5 \mathrm{~mm}$ (fig. 1). Simpler flasks without side arms are less suitable, because then oxalate oxidase is already present in the assay solution during the gassing with $\mathrm{O}_{2}$. This means that $\mathrm{CO}_{2}$ produced during gassing escapes measurement.

Procedure (tab. 1)

For oxalate determination, $125 \mu \mathrm{l}$ fresh, filtered urine from a sample collected over a known period is placed without pretreatment in the main chamber of the Warburg reaction flask, along with $2 \mathrm{ml}$ succinate buffer (I) and $5 \mu \mathrm{l}=1.3 \mathrm{kU}$ catalase. The central inner well contains $400 \mu \mathrm{l}$ alkaline buffer (II), and the side arm holds $400 \mu \mathrm{l}$ oxalate oxidase solution $(20 \mu \mathrm{g}$ protein). The flask is gassed through the open stopcock and capillary stopper with $0.251 \mathrm{O}_{2} / \mathrm{min}$, then the stopcocks, which are sealed with silicone grease, are closed. The flask is briefly inclined so that the enzyme flows out of the side arm into the main chamber. The oxalate is then converted to $\mathrm{CO}_{2}$, which diffuses into the alkaline buffer during the incubation at room temperature for at least $16 \mathrm{~h}$, and reduces its $\mathrm{pH}$ value. At the end of the incubation time, the central inner vessel can be removed and the $\mathrm{pH}$ value measured.

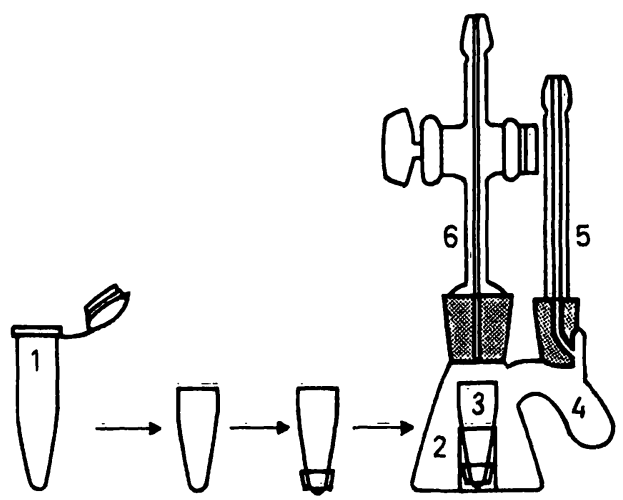

Fig. 1. Conical Warburg flask used for oxidative decarboxylation of oxalate.

1: Eppendorf-Netheler Cup, 2: main chamber (urine, buffer, catạlase), 3: central inner well (alkaline buffer), 4: side arm (oxalate oxidase), 5: capillary stopper, 6: stopcock, bore $1.5 \mathrm{~mm}$.

All vessels are gassed for $10 \mathrm{~min}$ with $\mathrm{O}_{2}(0.25 \mathrm{l} / \mathrm{min})$. Then the stopcocks are closed, and the solution from the side arm is tipped into the main chamber. The flask is gently shaken at room temperature. After at least $16 \mathrm{~h}$ incubation, the $\mathrm{pH}$ of the alkaline buffer in the central inner well is measured.

If a $\mathrm{pH}$ difference of 0.64 is obtained for $100 . \mathrm{nmol}$ oxalate, the oxalate concentration is

$\left(\overline{\mathrm{pH}}_{\mathrm{blank}}-\overline{\mathrm{pH}}_{\mathrm{assay}}\right) \times \frac{100}{0.64} \times 8\left[\frac{\mu \mathrm{mol}}{1}\right]$ 
Tab. 1. Scheme of oxalate determination in Warburg flasks. Each experiment is carried out in duplicate.

\begin{tabular}{|c|c|c|c|c|}
\hline & & Blank & Assay & Control \\
\hline & $\begin{array}{l}\text { All solutions gassed } \\
\text { with } \mathrm{O}_{2}(1 \mathrm{l} / \mathrm{min}) \\
\text { for } 30 \mathrm{~min}\end{array}$ & & & \\
\hline \multirow[t]{4}{*}{$\begin{array}{l}\text { Main } \\
\text { chamber }\end{array}$} & $\begin{array}{l}\text { Succinate } \\
\text { buffer }(I)[\mu \mid]\end{array}$ & 2000 & 2000 & 1000 \\
\hline & $\begin{array}{l}\text { Standard oxalate } \\
\text { solution (III) }[\mu l]\end{array}$ & - & - & 1000 \\
\hline & Urine $[\mu]]$ & 125 & 125 & 125 \\
\hline & Catalase $[\mu 1]$ & 5 & 5 & 5 \\
\hline \multirow[t]{2}{*}{ Side arm } & $\begin{array}{l}\text { Succinate } \\
\text { buffer }(I)[\mu l]\end{array}$ & 400 & - & - \\
\hline & $\begin{array}{l}\text { Oxalate } \\
\text { oxidase }[\mu 1]\end{array}$ & - & 400 & 400 \\
\hline $\begin{array}{l}\text { Central } \\
\text { inner well }\end{array}$ & $\begin{array}{l}\text { Alkaline } \\
\text { buffer (II) }[\mu 1]\end{array}$ & 400 & 400 & 400 \\
\hline
\end{tabular}

In addition to this $\mathrm{pH}$ value, an individual sample blank value must be determined. This $\mathrm{pH}$ value varies with the $\mathrm{O}_{2}$ gassing in different runs. The difference between sample and blank $\mathrm{pH}$ is then determined, and the oxalate content of the sample is calculated from a calibration curve.

\section{Results}

Figure 2 shows the linearity of the relationship between $\mathrm{pH}$ difference and oxalate content up to $200 \mathrm{nmol}$ per sample: $y=10.142-0.0064 x$. With the samples of $125 \mu l$ urine used in this procedure, oxalate concentrations of $80 \mu \mathrm{mol} / 1$ to $1.6 \mathrm{mmol} / 1(7.2 \mathrm{mg} / 1$ to $144 \mathrm{mg} / 1$ anhydrous oxalic acid, $M_{\mathrm{r}} 90.04$ ) are directly measurable.

In our experience, it is sufficient to set up a calibration curve once, since the same reproducible $\mathrm{pH}$ difference of 0.64 per $100 \mathrm{nmol}$ oxalate is obtained. Furthermore,

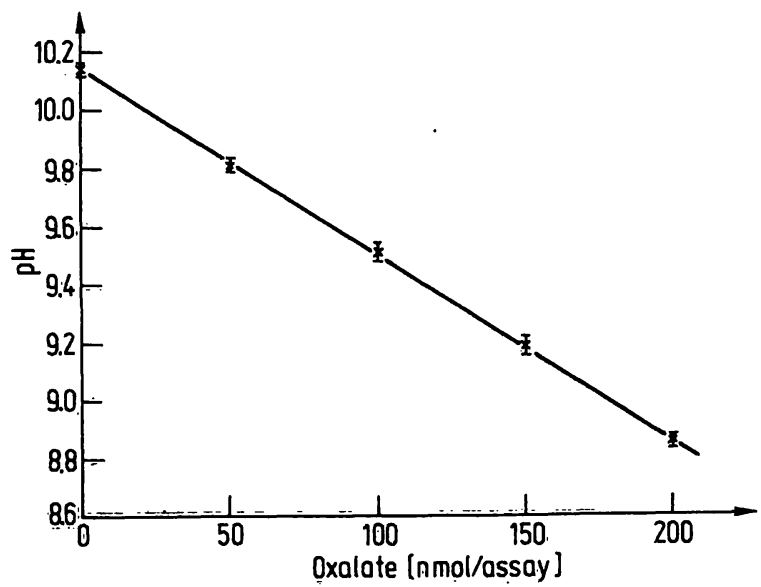

Fig. 2. Calibration curve for oxalate determination, $\overline{\mathbf{x}} \pm S D$, $\mathrm{n}=3 . \mathrm{CO}_{2}$ is generated from oxalate by oxalate oxidase and proportionätely reduces the ph value of an alkaline buffer. $100 \mathrm{nmol}$ oxalate correspond to a $\mathrm{pH}$ difference of $\mathbf{0 . 6 4}$.

Regression plot: $y=10.142-0.0064 x, r=0.9991$ $S_{\mathrm{yx}}=\mathbf{0 . 0 2 0 6 8}$ this can be checked by a standard control value for each sample. This is obtained by adding exactly $100 \mathrm{nmol}$ oxalate to the urine sample. However, it is not necessary to determine such a standard control value for every single urine sample; it is enough to make one check for each experimental series to test the system.

Blank values for enzymes and for oxalate were negligible with our preparation; the latter did not change with various amounts of exogenously added oxalate.

\section{Effect of catalase}

As explained in the introduction, the catalase added to the mixture decomposes the $\mathrm{H}_{2} \mathrm{O}_{2}$ generated in the oxalate oxidase reaction. This accelerates the reaction and halves the amount of oxygen required. It can be seen from the experiment shown in figure 3 that the addition of catalase can reduce the amount of oxalate oxidase required. We therefore added $1.3 \mathrm{kU}$ catalase to each sample. In principle, however, catalase is not needed if sufficient oxalate oxidase activity is present.

\section{Amount of oxalate oxidase}

Urine contains numerous cations and anions which reduce the activity of the oxalate oxidase (6). Therefore more enzyme must be added to biological samples than to aqueous solutions. As can be seen from figure 4, a quantitative determination of urine oxalate is only possible under the given experimental conditions when at least $20 \mu \mathrm{g}$ oxalate oxidase is added. This amount has been sufficient in every urine sample so far examined, as was determined from the quantitative recovery of $100 \mathrm{nmol}$ added oxalate.

\section{Time required for diffusion}

To determine the amount of time necessary for diffusion, the oxalate in the main chamber was replaced by $150 \mathrm{nmol} \mathrm{Na} 2 \mathrm{CO}_{3}$, so that all the $\mathrm{CO}_{2}$ would be imme-

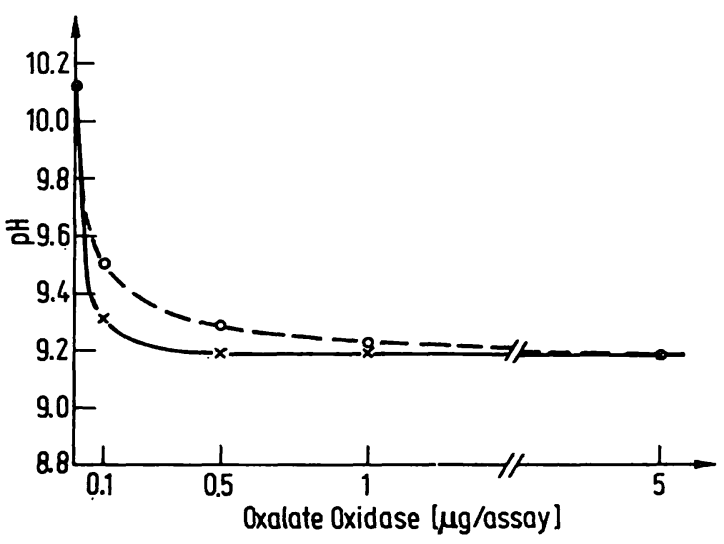

Fig. 3. Reduction of the amount of oxalate oxidase needed by addition of catalase. $\mathrm{pH}$ value after $16 \mathrm{~h}$ incubation of $150 \mathrm{nmol}$ oxalate as a function of oxalate oxidase and with added catalase.

$x=$ with catalase, $1.3 \mathrm{kU} /$ assay

$0=$ without catalase 


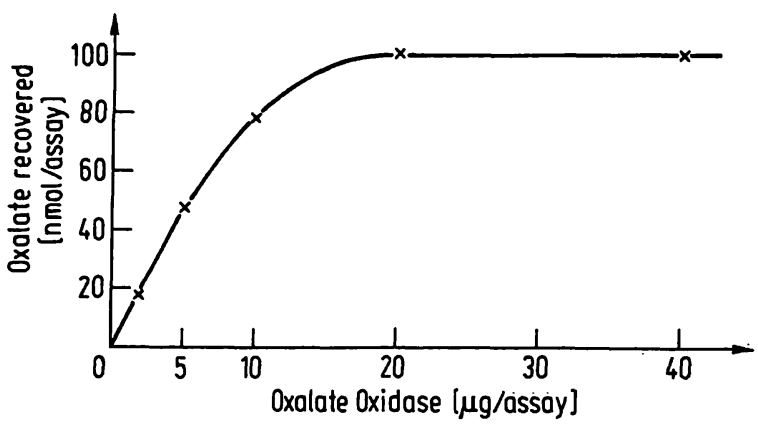

Fig. 4. Recovery of oxalate.

$100 \mathrm{nmol}$ oxalate was added to a pooled urine sample and the recovery was plotted as a function of oxalate oxidase.

diately released on addition of $\mathrm{H}_{2} \mathrm{SO}_{4}$ instead of enzyme from the side arm. The other conditions were the same as in the regular determination. The experiment served to measure the time required for diffusion independently of the enzymatic formation of $\mathrm{CO}_{2}$. Figure 5 shows that the $\mathrm{pH}$ value of the alkaline buffer becomes constant only after $16 \mathrm{~h}$. The oxalate cannot be more rapidly analysed with this system, and the time required for diffusion is prolonged by about $1 / 3$ when the incubation flasks are not shaken.

The length of time required for diffusion is advantageous, however, for the $\mathrm{pH}$ measurement after incubation, because the $\mathrm{CO}_{2}$ from the air has no effect during the time required for this procedure.

\section{Urine oxalate values in normal subjects}

The oxalate concentration in the urine of 6 healthy persons was measured (tab. 2). The values obtained ranged from 123 to $345 \mu \mathrm{mol} / \mathrm{l}$.

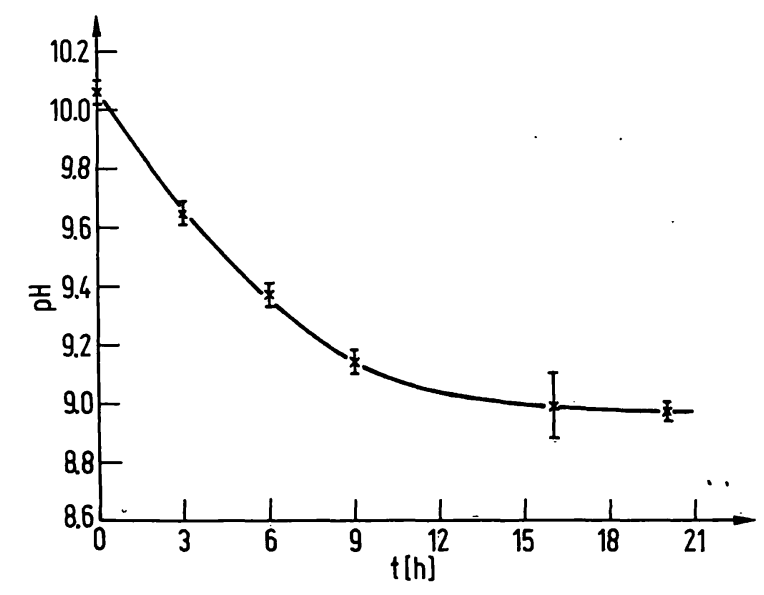

Fig. 5. Dependence of the measured $\mathrm{pH}$ value on the diffusion time. At the beginning of the experiment, $\mathrm{CO}_{2}$ was released from $150 \mathrm{nmol} \mathrm{Na} \mathrm{CO}_{3}$ with $\mathrm{H}_{2} \mathrm{SO}_{4}$. $\bar{x} \pm S D(n=3)$.
Tab. 2. Oxalate contents in urine of normal persons.

Each value is the mean of duplicate determinations.

\begin{tabular}{llll}
\hline Urine sample & $\begin{array}{l}\text { Oxalate } \\
\text { concentration }\end{array}$ & $\begin{array}{l}\text { Oxalate } \\
\text { excretion }\end{array}$ & $\begin{array}{l}\text { Recovery of } \\
100 \mathrm{nmol} \\
\text { oxalate } \\
{[\text { [nmol] }}\end{array}$ \\
\hline $1 \mu \mathrm{mol} / \mathrm{l}]$ & {$[\mu \mathrm{mol} / 24 \mathrm{~h}]$} & 418 & 109 \\
2 & 345 & 357 & 100 \\
3 & 258 & 53 & 102 \\
4 & 123 & 141 & 98 \\
5 & 266 & 395 & 92 \\
6 & 197 & 223 & 103 \\
$\bar{x} \pm$ SD & 123 & $265 \pm 149$ & $100.7 \pm 5.7$ \\
& $219 \pm 88$ & & $\mathrm{CV}=5.6 \%$ \\
\hline
\end{tabular}

\section{Criteria of the method}

We determined the following values as criteria of the method:

\section{Limit of detection}

The limit of detection according to Kaiser (7) is $10 \mathrm{nmol}$ oxalate.

\section{Specificity}

The enzyme oxalate oxidase converts only oxalate, specifically. No other substrates could be found.

\section{Accuracy}

$100 \mathrm{nmol}$ oxalate was added to each of 6 different samples of urine. On the average $100.7 \pm 5.7 \mathrm{nmol}$ was recovered (lowest value 92, highest value 109). Coefficient of variation $=5.6 \%$ (see table 2$)$.

\section{Reproducibility}

The reproducibility among a series of $n=6$ was $266 \pm 14 \mu \mathrm{mol} / 1$, corresponding to a coefficient of variation of $5.3 \%$. From day to day, with $n=5$, we found $257 \pm 19 \mu \mathrm{mol} / \mathrm{l}$, corresponding to a coefficient of variation of $7.4 \%$.

\section{Discussion}

Oxidation of oxalate by oxalate oxidase produces $2 \mathrm{~mol} \mathrm{CO}_{2}$, while oxalate decarboxylase yields only $1 \mathrm{~mol} \mathrm{CO}_{2}$. If $\mathrm{CO}_{2}$ is measured as the reaction product of an enzymatic oxalate conversion, then the sensitivity with oxalate oxidase should be twice that with oxalate decarboxylase, i. e. the $\mathrm{pH}$ difference measured with the present technique should be twice as great. Üsing our experimental set up we measured the $\mathrm{pH}$ changes in the alkaline buffer as a function of the amount of oxalate (fig. 6) with each of the two enzymes. As expected, the $\mathrm{pH}$ difference with oxalate oxidașe is twice that with 


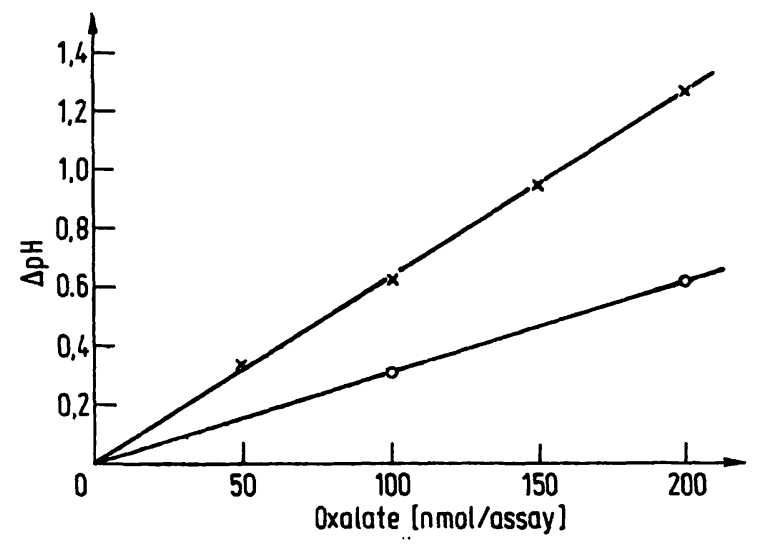

Fig. 6. Comparison of oxalate determination with oxalate oxidase and oxalate decarboxylase. $20 \mu \mathrm{g}$ oxalate oxidase or $0.37 \mathrm{U}$ oxalate decarboxylase was added to convert the oxalate. The $\mathrm{pH}$ difference measured with oxalate oxidase is twice that with oxalate decarboxylase, since the former produces twice as much $\mathrm{CO}_{2}$. $x=$ Oxalate oxidase $0=$ Oxalate decarboxylase

oxalate decarboxylase and is 0.64 for $100 \mathrm{nmol}$ oxalate, compared to 0.32 . The limit of detection was reduced in this way to 10 nmol oxalate. Since the reaction flask holds a maximum of $3 \mathrm{ml}$ sample volume, this corresponds to a minimal oxalate concentration in the sample to be analysed of $3 \mu \mathrm{mol} / 1$.

This limiting concentration is so low that it appears possible to analyse serum, which has an oxalate concentration of 15-30 $\mu \mathrm{mol} / 1$. However, prior to analysis $25 \mathrm{mmol}$ endogenous $\mathrm{CO}_{2} / 1$ would have to be removed.

The low limit of detection and the wide range of 10-200 nmol oxalate make it possible to dilute urine by maximally $1: 25$. We used a dilution of $1: 20$. The ions which inhibit oxalate oxidase activity (6) are thus sufficiently dilute that economical amounts of enzyme can be used. In addition, the concentrations, and thus effectiveness of other possible interfering substances, such as previously unknown inhibitors of oxalate oxidase, are reduced. In principle, the method described, measurement of $\mathrm{CO}_{2}$ released from oxidation of oxalate after diffusion into an alkaline buffer, is not very sensitive to interference. Neither oxidizing nor reducing substances interfere, and cloudy or colored samples can be used. This makes the technique independent of the type of sample. It can be used not only for urine, but also for determination of oxalate in food technology and plant breeding.

\section{References}

1. Hallson, P. C. \& Rose, G. A. (1974), Clin. Chim. Acta 55, 29-39.

2. Hodgkinson, A. (1978), Oxalic Acid in Biology and Medicine, Academic Press, London 1978, 360 pp.

3. Jakoby, W. B. (1974), Oxalat, in: Methoden der enzymatischen Analyse (Bergmeyer, H. U., ed.), 3. Aufl., Bd. 2, 1587-1590, Verlag Chemie, Weinheim/Bergstraße.

4. Datta, P. K. \& Meeuse, B. J. D. (1955), Biochim. Biophys. Acta 17, 602-603.

5. Chiriboga, J. (1966), Arch. Biochem. Biophys. 116, 516523.

6. Chiriboga, J. (1963), Biochem. Biophys. Res. Comm. 11, 277-282.

7. Kaiser, H. (1965), Z. Analyt. Chem. 209, 1-18.
Dipl.-Biochem. Günther Kohlbecker Institut für Molekularbiologie und Biochemie der Freien Universität Berlin Arnimallee 22 D-1000 Berlin 33 


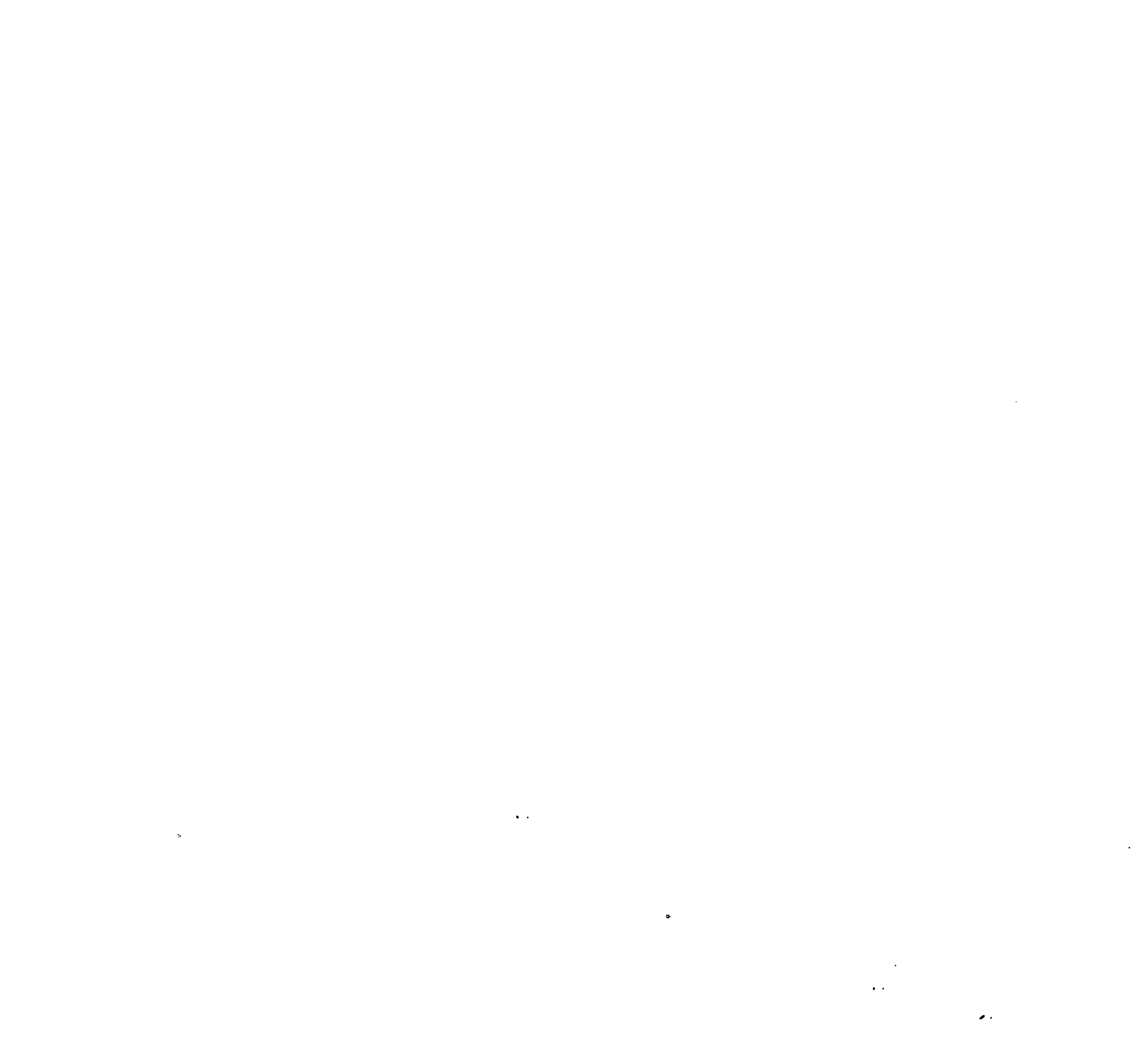

